\title{
Pseudomonas aeruginosa Exotoxin A Induces Apoptosis in Chemoresistant YD-9 Human Oral Squamous Carcinoma Cell Line Via Accumulation of p53 and Activation of Caspases
}

\author{
Gyoo-Cheon Kim ${ }^{1}$ and Young-Gi Gil* \\ Department of Anatomy College of Medicine, Kosin University, Busan 602-703, Korea \\ ${ }^{1}$ Department of Oral Anatomy School of Dentistry, Pusan National University, Busan 602-739, Korea,
}

Received May 13, 2009 / Accepted May 20, 2009

\begin{abstract}
Oral squamous carcinoma (OSC) cells present resistance to chemotherapeutic agents-mediated apoptosis in the late stages of malignancy. Advances in the understanding of bacterial toxins have produced new strategies for the treatment of cancers. It was demonstrated here that Pseudomonas aeruginosa exotoxin A (PEA) significantly decreased the viability of chemoresistant YD-9 cells in the apoptosis mechanism. Apoptotic manifestations were evident through changes in nuclear morphology and generation of DNA fragmentation. PEA treatment induced caspase-3, -6 and -9 cleavage, and activation. These events preceded proteolysis of the caspase substrates poly (ADP-ribose) polymerase (PARP), DNA fragmentation factor 45 (DFF45), and lamin A in YD-9 cells. The reduction of mitochondrial membrane potential, release of cytochrome $\mathrm{c}$ and Smac/DIABLO from mitochondria to cytosol, and translocation of AIF into nucleus were shown. While p53, p21 and 14-3-3y were upregulated, cyclin $\mathrm{B}$ and cdc2 were downregulated by PEA treatment. Taken together, PEA induces apoptosis in chemoresistant YD-9 cells via activation of caspases, mitochondrial events and regulation of cell cycle genes.
\end{abstract}

Key words : Oral squamous carcinoma, apoptosis, P. aeruginosa exotoxin A, caspase

\section{Introduction}

It has been reported that the mass size of mammalian cancers was reduced when they were infected with microbial pathogens [6,25]. Furthermore, bacteria such as Shigella flexneri, Salmonella typhimurium and Staphylococcus aureus were shown to induce apoptosis by the inhibition of survival pathways and the secretion of molecules activating the endogenous death machinery in the infected cell [11]. Considering that most tumors contain poorly vascularized areas, recent studies used anaerobic bacteria for treatment of cancer, resulting in significant regression of subcutaneous tumors [8]. However, the application of live bacteria produces significant toxicity and side effects [8,17], limiting the use of bacteria in the treatment of human cancer [15].

Thus, bacterial toxins have emerged as powerful therapeutic agents with possible applications in cancer. Several bacterial toxins were used not only in the forms of immuntoxin, which is composed of antibodies linked to bacterial toxins [26,4], but in purified forms $[1,21,23]$. Purified bacterial toxins such as shiga toxin, cholera toxin and vacuolat-

*Corresponding author

Tel : +82-51-990-6412, Fax : +82-51-990-6438

E-mail : tomy88@ns.kosinmed.or.kr ing cytotoxin showed apoptosis-inducing activity in cancer cells $[5,23]$.

$P$. aeruginosa frequently causes pneumonia, septicemia, and other acute infections in immunocompromised patients. This gram-negative bacterium produces several extracellular products such as proteases, hemolysins, exotoxin A, exoenzyme $\mathrm{S}$, elastase and pyocyanin [33]. Among them, $P$. aeruginosa exotoxin A (PEA) is known to be the most toxic factor secreted by $P$. aeruginosa. PEA enters into eukaryotic cells via receptor mediated endocytosis, and then is cleaved in the endocytic vesicles and translocated into the cytoplasm, where it catalyzes the transfer of the ADP-ribosyl moiety of $\mathrm{NAD}^{+}$to elongation factor 2 (EF-2). This inactivation of EF-2 in cells infected with $P$. aeruginosa is shown to lead inhibition of proteins synthesis, resulting in host cell death [16].

Human oral squamous carcinoma (OSC) is responsible for the majority of malignancies in the oral cavity. Treatment of OSC has primarily relied on classical modalities encompassing surgery, radiation and chemotherapy or a combination of these methods, but the result showed the lowest 5 years survival rate among the major cancers. At the late stage of malignancy, OSC cells are highly resistant to cancer-therapy-mediated apoptosis $[7,32]$. Chemoresistance in cancers is 
a frequent impediment to successful chemotherapy. Thus, the selective removal of OSC cells by inducing apoptosis could be a promising strategy for treatment of OSC.

The present study was undertaken to investigate whether PEA has an anti-tumor activity in a highly chemoresistant OSC cell line YD-9 cells. I here demonstrate that PEA has a strong cytotoxic effect and induces apoptosis caspases- and mitochondria-dependently in YD-9 cells.

\section{Materials and Methods}

The following reagents were obtained commercially.

\section{Antibodies}

Mouse monoclonal anti-human caspase-9, cytochrome c, Lamin A and Smac/DIABLO and caspase- 6 antibodies were from Upstate biotechnology (Lake Placid, NY, USA). Mouse monoclonal anti-human caspase-3 and PARP, p53, p21, cdc2 and cyclin B1, and rabbit polyclonal anti-human AIF and 14-3-3 $\gamma$ were from Santa Cruz Biotechnology (Santa Cruz, CA, USA). Mouse monoclonal anti-human DFF45 antibody was from MBL (Naka-ku, Nagoya, Japan).

\section{Agents}

PEA, Dimetyl sulfoxide (DMSO), Hoechst33258, RNase A, proteinase $\mathrm{K}$, aprotinin, leupeptin, PMSF, thiazolyl blue tetrazolium bromide (MTT) were from Sigma Aldrich (St. Louis, MO, USA). TUNEL reaction mixture was from Roche Molecular Biochemicals (Mannheim, Germany). ECL Western blotting detection reagents were from Amersham International (Buckinghamshire, UK) 5,5',6,6'-tetrachloro1,1',3,3'-tetraethylbenzimidazol carbocyanine iodide (JC-1) were from Biotium (Hayward, CA. USA).

\section{Cell culture}

YD-9 cell that established from OSC patient [22] were a generous gift of Professor Jong-In Yook (College of Dentistry, Yonsei University, Seoul, Korea). The cells were cultured at $37^{\circ} \mathrm{C}$ in a humidified atmosphere containing $5 \%$ $\mathrm{CO}_{2}$ in Dulbecco's modified Eagles medium: Nutrient Mixture F12 (DMEM/F12, 3:1) supplemented with 10\% heat-inactivated fetal bovine serum (FBS), 1\% glutamine, and $100 \mu \mathrm{g} / \mathrm{ml}$ penicillin/streptomycin.

\section{Cell viability assay}

The viability of cultured cells was estimated by MTT assay. In the MTT assay, cells were placed in a 96-well plate and incubated for $24 \mathrm{hr}$. Then cells were treated with PEA at $0,1.5,7.5,15,30$ and $60 \mathrm{nM}$ for $24 \mathrm{hr}$. And then, the cells were treated with $1 \mathrm{mg} / \mathrm{ml}$ of MTT in growth medium. Cells were incubated at $37^{\circ} \mathrm{C}$ for $4 \mathrm{hr}$. The medium was aspirated and the formazan crystals, which are formed from MTT by NADH-generating dehydrogenases in metabolically active cell, were dissolved in $200 \mathrm{ml}$ DMSO. Cell viability was evaluated in comparison to the control culture (taken as $100 \%$ ) by measuring the intensity of the blue color (OD at $570 \mathrm{~nm}$ ) by a multiwell reader Quant spectrophotometer (BIO-TEK Instruments Inc., Winooski, VT, USA). Independent experiments were undertaken and each experiment was conducted in triplicates.

\section{TUNEL assay}

To detect DNA breaks in situ, the TUNEL assay was conducted with an TUNEL reaction mixture kit (Boehringer Mannheim, Germany). After PEA treatment, cells were washed twice with PBS, fixed in $4 \%$ paraformaldehyde for $30 \mathrm{~min}$, and applied permeabilisation solution for $5 \mathrm{~min}$ at $4^{\circ} \mathrm{C}$, and washed again with PBS. This was followed by in situ end labeling according to the manufacturer's instructions.

\section{Hoechst staining}

Cells treated with PEA for $24 \mathrm{hr}$ and the cell suspension was centrifuged onto a clean fat-free glass slide with a cytocentrifuge. The samples were stained $4 \mu \mathrm{g} / \mathrm{ml}$ Hoechst 33258 at $37^{\circ} \mathrm{C}$ for $30 \mathrm{~min}$ and fixed for $10 \mathrm{~min}$ in $4 \%$ paraformaldehyde.

\section{DNA electrophoresis}

$2 \times 10^{6}$ cells were resuspended in $1.5 \mathrm{ml}$ of lysis buffer [10 $\mathrm{mM}$ Tris (pH 7.5), $10 \mathrm{mM}$ EDTA (pH 8.0), $10 \mathrm{mM} \mathrm{NaCl}$ and $0.5 \% \mathrm{SDS}$ ] into which proteinase $\mathrm{K}(200 \mu \mathrm{g} / \mathrm{ml})$ was added. After samples were incubated overnight at $48^{\circ} \mathrm{C}, 200 \mu \mathrm{l}$ of ice cold $5 \mathrm{M} \mathrm{NaCl}$ was added and the supernatant containing fragmented DNA was collected after centrifugation. The DNA was then precipitated overnight at $-20^{\circ} \mathrm{C}$ in $50 \%$ isopropanol RNase A-treated for $1 \mathrm{hr}$ at $37^{\circ} \mathrm{C}$. A loading buffer containing $100 \mathrm{mM}$ EDTA, $0.5 \%$ SDS, 40\% sucrose, and $0.05 \%$ bromophenol blue were added at $1: 5(\mathrm{v} / \mathrm{v})$. Separation was achieved in $2 \%$ agarose gels in Tris-acetic acid/EDTA buffer (containing $0.5 \mu \mathrm{g} / \mathrm{ml}$ ethidium bromide) using 50 $\mathrm{mA}$ for $1.5 \mathrm{hr}$ 


\section{Western blot analysis}

Cells $\left(2 \times 10^{6}\right)$ treated with PEA were washed twice with ice-cold PBS, resuspended in $200 \mu$ ice-cold solubilizing buffer [300 mM NaCl, $50 \mathrm{mM}$ Tris-Cl (pH 7.6), 0.5\% TritonX-100, $2 \mathrm{mM}$ PMSF, $2 \mu \mathrm{l} / \mathrm{ml}$ aprotinin and $2 \mu \mathrm{l} / \mathrm{ml}$ leupeptin] and incubated at $4^{\circ} \mathrm{C}$ for $30 \mathrm{~min}$. The lysates were centrifuged at 14,000 revolutions per $\min$ for $15 \mathrm{~min}$ at $4^{\circ} \mathrm{C}$. Protein concentrations of cell lysates were determined with Bradford protein assay (Bio-Rad, Richmond, CA, USA) and $50 \mu \mathrm{g}$ of proteins were loaded onto $7.5-15 \%$ SDS/PAGE. The gels were transferred to nitrocellulose membrane and reacted with each antibody. Immunostaining with antibodies was performed using Super Signal West Pico enhanced chemiluminescence substrate and detected with LAS3000PLUS (Fuji Photo Film Company, Kanagawa, Japan).

\section{Immunofluorescent staining}

Cells were cytocentrifuged and fixed for $10 \mathrm{~min}$ in $4 \%$ paraformaldehyde, incubated with anti-cytochrome c, Smac/DIABLO and AIF antibodies for $1 \mathrm{hr}$, washed 3 times each for $5 \mathrm{~min}$, and then incubated with goat-FITC-anti-mouse or rabbit IgG secondary antibody (Santa Cruz Biotechnology, Santa Cruz, CA, USA) for $1 \mathrm{hr}$ at $37^{\circ} \mathrm{C}$. Cells were mounted with PBS, and observed under Zeiss Axioscop (Germany).

\section{Assay of mitochondrial membrane potential (MMP)}

Changes in mitochondrial membrane potential after treatment with PEA for $24 \mathrm{hr}$ were determined by staining cells with the indicator dye. JC- 1 was added directly to the cell culture medium ( $1 \mu \mathrm{M}$ final concentration) and incubated for $15 \mathrm{~min}$. The medium was then replaced with PBS, and cells were quantitated for J-aggregated fluorescence intensity in a modular fluorimetric system (Spex Edison, NJ, USA) using excitation and emission filters of 492 and $590 \mathrm{~nm}$, respectively.

\section{Results}

\section{PEA reduced the viability of YD-9 cells}

To investigate whether PEA has a cytotoxic effect on YD-9 cells, MTT assay was conducted. As well known chemoresistant osteosarcoma cell lines such as HOS and MG63, YD-9 cells did not significant decrease in cell viability after treatment with etoposide $(2-10 \mu \mathrm{g} / \mathrm{ml})$ and 5-FU $(1-2000 \mu$ $\mathrm{M})$ at which concentration many cancer cells are responsive. Furthermore, YD-9 cells proliferation were rarely affected by various concentrations of another antitumor agent genistein (data not shown). However, PEA at 1.5-60 nM substantially reduced the viability of those cells. Noticeably, cell death inducing activity of PEA is significantly higher in YD-9 cells, compared with HOS and MG63 cells (Fig. 1). Since PEA showed the highest cytotoxicity in YD-9 cells among three cells, the mechanism underlying its cytotoxicity was studied on this single cell. For this study, the single concentration $15 \mathrm{nM}$ was utilized for further assessment of apoptosis, at which PEA showed half-maximal inhibition of viability.

Reduced viability of YD-9 cells induced by PEA resulted from apoptosis

I examined whether reduced viability of YD-9 cells were caused by apoptosis. Hoechst staining showed nuclear condensation and fragmentation after treatment of $15 \mathrm{nM}$ PEA for $24 \mathrm{hr}$ (Fig. 2A). In TUNEL assay, a large number of cells treated with $15 \mathrm{nM}$ PEA for $24 \mathrm{hr}$ showed positive reaction (Fig. 2B). Cells treated with $15 \mathrm{nM}$ PEA showed DNA degradation characteristic of apoptotic ladder (Fig. 2C).
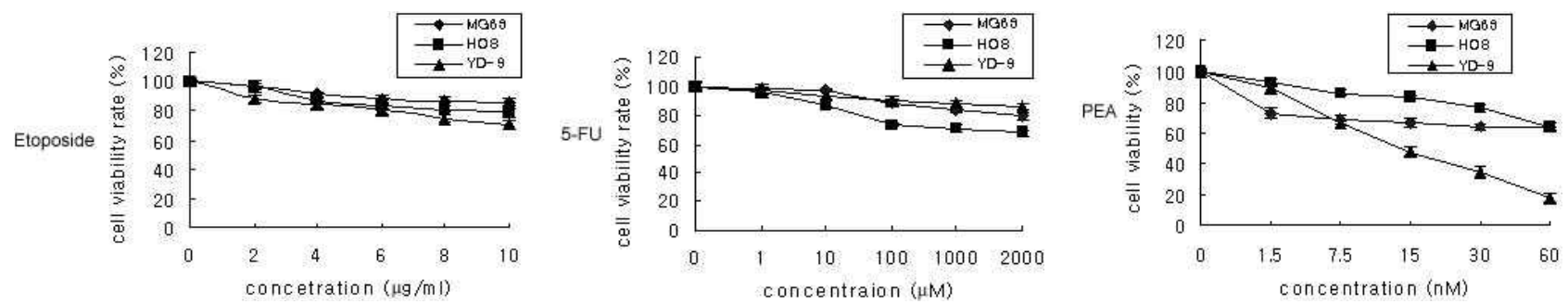

Fig. 1. Effects of PEA treatment on the viability of chemoresistant YD-9 cells. After $24 \mathrm{~h}$ incubation with etoposide $(2-10 \mu \mathrm{g} / \mathrm{ml})$ and 5-FU $(1-2000 \mu \mathrm{M})$, viabilities were determined by MTT assay. All of three cell lines showed resistance to etoposide and 5-FU. HOS, MG63 and YD-9 cells were treated with PEA (1.5-60 nM). PEA preferentially decreased the proliferation of YD-9 cells compared with other cell lines. Four independent assays were performed and data shown are the mean \pm SD of the means obtained from triplicates of each assay. 


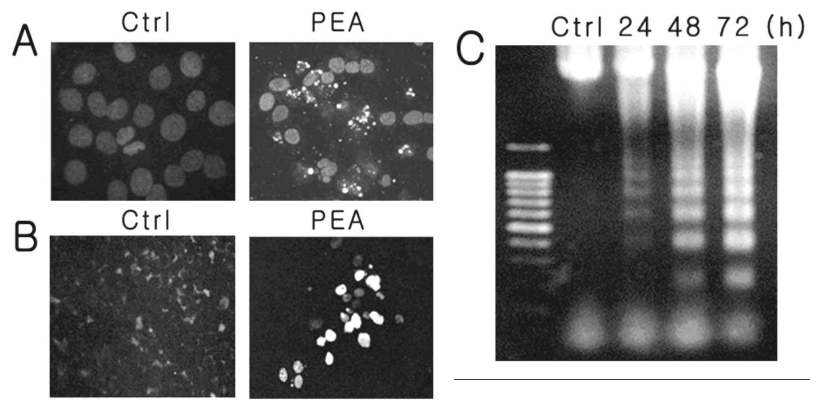

Fig. 2. Demonstration of apoptosis in YD-9 cells treated with $15 \mathrm{nM}$ PEA . (A) Nuclear condensation and fragmentation were clearly shown by Hoechst staining. (B) TUNEL assay showed apoptotic cells in YD-9 cells treated with PEA. (C) DNA electrophoresis showed DNA ladder in YD-9 cells treated with PEA.

Mitochondrial events were involved in PEA-induced apoptosis of YD-9 cells

Loss of MMP $(\Delta \Psi \mathrm{m})$ is known to be a common event in many pathways of apoptosis. In this study, MMP decreased time-dependently after PEA treatment (Fig. 3A). I further examined the subcellular location of mitochondrial apoptosis related factors after PEA treatment. Immunofluorescent microscopy revealed that cytochrome $\mathrm{c}$ and Smac/DIABLO in control cells are shown in a punctuate pattern. However, it assumed a diffuse distribution in PEA-treated cells which supported the notion that PEA led to the release of those proteins from mitochondria into cytosol (Fig. 3B). On the other hand, the AIF protein which had been mainly distributed out of the nucleus in the control cells was translocated onto nucleus following treatment of PEA (Fig. 3B).

PEA-induced apoptosis of YD-9 cells was caspases-dependent

To examine whether the apoptosis was mediated via caspases, I carried out Western blotting experiments. Western blotting analysis showed that PEA activated an initiator caspase-9 and the two effector caspases caspase-3 and -6 . Not only degradation of caspase-9, -3 and -6 were shown, but cleaved products of each caspase were also demonstrated (Fig. 4).

PEA treatment caused cleavage of various caspase target proteins

The effects of PEA on caspase target proteins such as DFF45, PARP and lamin A was investigated. As shown in Figure 5, degradation of PARP protein $(116 \mathrm{kDa})$ and production of PARP $85 \mathrm{kDa}$ cleavage products were shown. The
(A)

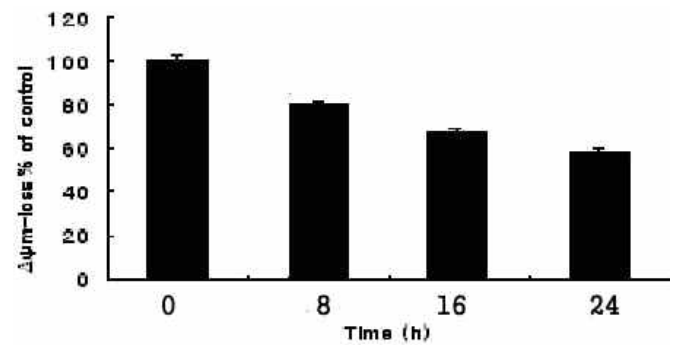

(B)

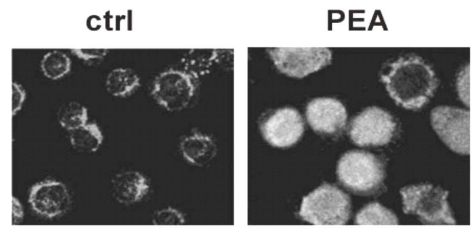

cytochrome c

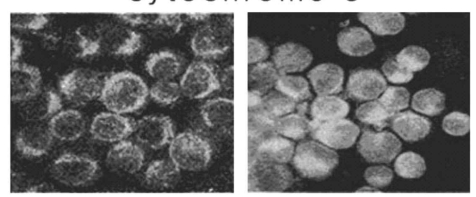

Smac/DIABLO

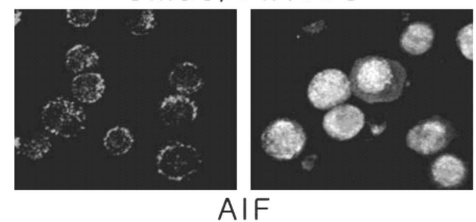

Fig. 3. Demonstration of mitochondrial events in YD-9 cells treated with $15 \mathrm{nM}$ PEA. (A) MMP decreased after PEA treatment. (B) Immunofluorescence microscopy. In the control YD-9 cells, cytochome c, Smac/DIABLO and AIF are loacated in mitochondria. $24 \mathrm{hr}$ after treatment with PEA, cytochrome $c$ and Smac/ DIABLO are observed in the cytosol. Note that AIF was redistributed into nucleus following treatment of cells with PEA.

cleaved products of DFF45 (30 and $11 \mathrm{kDa}$ ) and lamin A (45 and $28 \mathrm{kDa}$ ) were observed.

PEA treatment induced upregulation or downregulation of cell cycle regulatory

I next asked whether PEA could modulate cell cycle regulatory protein. I examined alterations in protein levels using antibodies against key players in cell cycle regulation (Fig. 6). Western blot analysis demonstrated that mutant type p53 increased at 8,16 and $24 \mathrm{hr}$, and then decreased. The expression of 14-3-3 $\gamma$ and p21 were increased up to $24 \mathrm{hr}$, whereas a significant downregulation of cdc2 and cycline $B$ was detected in time-dependent manner.

\section{Discussion}

I have shown that PEA in the form of purified protein 


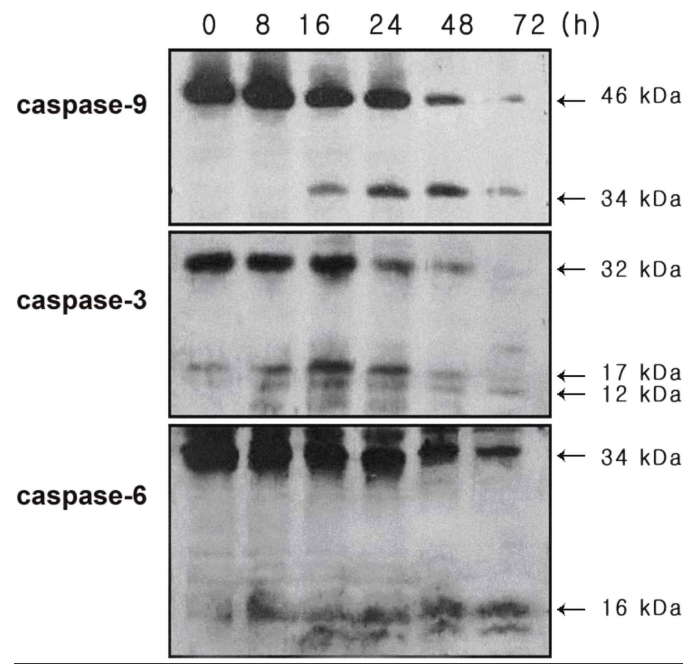

Fig. 4. Activation of caspases in YD-9 cells treated with15 nM PEA. Proform caspase-9 (46 kDa) was degraded, and 34 $\mathrm{kDa}$ cleaved product was produced after PEA treatment. Proform of caspase-3 (32 kDa) was degraded, and $17 \mathrm{kDa}$ and $12 \mathrm{kDa}$ cleaved forms were produced after PEA treatment. Caspase-6 pro-enzyme $(34 \mathrm{kDa})$ was degraded, and $16 \mathrm{kDa}$ cleaved forms were produced after PEA treatment.

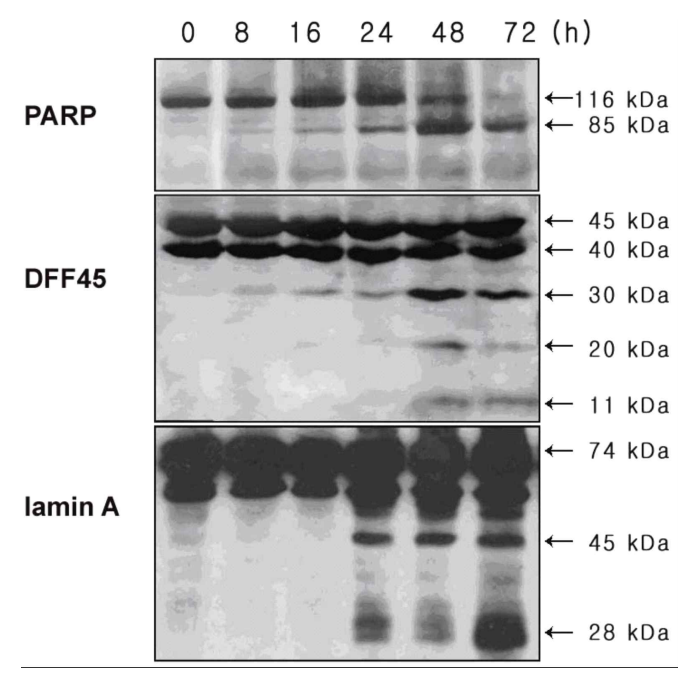

Fig. 5. Degradation of caspase target proteins in YD-9 cells treated with 15 nM PEA. Degradation of PARP protein (116 $\mathrm{kDa}$ ) and production of $85 \mathrm{kDa}$ cleavage product were demonstrated, which is prominent $24 \mathrm{hr}$ after PEA treatment. Three cleaved products of DFF45 (30, 20 and $11 \mathrm{kDa}$ ) were demonstrated in YD-9 cells treated with PEA, which are evident in later time points (48 and 72 $\mathrm{hr}$ ). Two cleaved products of lamin A (45 and $28 \mathrm{kDa}$ ) are demonstrated in YD-9 cells treated with PEA, which are shown at $24 \mathrm{hr}$ after PEA treatment.

has a strong cytotocic effect on cheomresistant YD-9 OSC cells through inducing apoptosis. Chemoresistant tumor

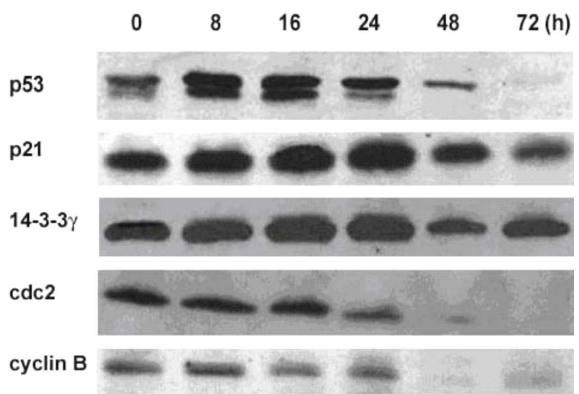

Fig. 6. Western blot analysis of cell cycle regulation proteins in YD-9 cells treated with $15 \mathrm{nM}$ PEA. The expression of p53 was increased at 8,16 and $24 \mathrm{hr}$, and then decreased. The expression of p21 and 14-3-3 $\gamma$ were increased up to $24 \mathrm{hr}$, whereas the expression level of cdc2 and cyclin B were decreased time-dependently.

cells have acquired the ability to evade the action of multiple classes of anti-cancer drugs. One mechanism by which tumor cells survive in the presence of chemotherapy is the increase of anti-apoptotic activities. Because resistance to chemotherapy is a major failure in the treatment of OSC, there is a great interest in the search for new compounds that may destroy OSC cells, which eventually can be incorporated into therapy for the treatment of OSC.

In the past two decades, bacterial toxins have been considered as potential therapeutic agents for treatment of cancer. The application of anthrax lethal factor to athymic nude mice carrying human melanoma xenograft induced complete tumor regression without side effects [21]. Verotoxin 1 has been proven to be highly effective in human colon cancer [3], myelogenous leukemia cells [23] and renal tumor xenografts in SCID mice [14].

A number of extracellular toxic products, which $P$. aeruginosa synthesizes, are believed to be involved in the pathogenesis of its infection. Among those products, PEA is considered to be the most toxic factor [12]. PEA is a $66 \mathrm{kDa}$ protein which has three structurally and functionally different domains. Domain I is responsible for cell recognition, domain II for translocation, and domain III for inhibition of protein synthesis [27]. It is generally accepted that PEA is internalized by the cell surface receptor CD91 and exhibits its cytotoxicity by blocking protein synthesis through inactivation of EF-2 [16]. However, it was reported that protein synthesis inhibition by toxins is not sufficient to mediate target cell death [24], suggesting that additional mechanisms such as apoptosis may be involved in PEA-induced cytotoxicity.

Previous studies elucidated that PEA induces cellular 
death via apoptosis in normal cells including mouse hepatocyte [30] and human mast cells [18]. Because of its apoptosis-inducing activity, PEA has been widely used to kill target cells. In most studies undertaken for the purpose of cancer treatment, PEA has been employed in the form of immunotoxin. PEA-containing immunotoxin induced apoptosis in breast cancer cells [2] and leukemia cells [9]. Although PEA-containing immunotoxin has been studied in various cancer cells, induction of apoptosis in cancer cells by PEA in the form of purified protein has not been demonstrated to date. I here demonstrated the induction of apoptosis in chemoresistant cancer cells by purified PEA.

Etoposide and 5-FU are known to inhibit the proliferation of various cancer cells $[13,29]$. They have been widely used in treatment of OSC and reported inducing apoptosis in OSC cells. However, etoposide and 5-FU at usual doses did not inhibit substantially the proliferation of YD-9 cells. Furthermore, genistein, at the doses inducing substantially apoptosis in human osteosarcoma cells, did not affect the viability in YD-9 cells [28]. My experimental results demonstrated that YD-9 cells are resistant to etoposide, 5-FU and genistein. Nevertheless, PEA at nanomolar concentrations strongly inhibited the growth of YD-9 cells dose-dependently, suggesting that PEA has a preferential cytotoxic effect on YD-9 chemoresistant OSC cells.

Caspases and mitochondria play an important role in the execution phase of apoptosis and are responsible for many of the biochemical and morphological changes associated with apoptosis. Caspases are known to cleave a number of proteins and the consequences of these cleavage events were suggested to be responsible for many of the phenotypic changes in the cell undergoing apoptosis [34]. Mitochondria play a critical role in control of apoptosis by acting as reservoirs for death promoting factors such as cytochrome $c$, Smac/Diablo, AIF, endonuclease $G$ and procaspases-2, $-3,-8$, -9 [10].

When bacteria toxins induce apoptosis in cancer cells, both caspase and mitochondria also play an important role. Shiga toxin 1 induces apoptosis in the human myelogenous leukemia cell line THP-1 [23] and in Burkitt's lymphoma cells [19] by a caspase-dependent mechanism. Diphtheria toxin contributes to apoptosis in human leukemia cells through caspase activation [31]. PTE-containing immunotoxin induced loss of mitochondrial membrane potential and activation of the caspase cascade in MA-11 breast cancer cells [2]. My data indicate that PEA also induces apoptosis on
YD-9 OSC via activation of caspases and mitochondrial events.

Usually p53 acts as an "emergency break" inducing either cell cycle arrest or apoptosis, protecting the genome from accumulating excess mutations. In response to stimuli, p53 is stabilized and activated by multiple mechanisms (including phosphorylation, dephosphorylation and acetylation). Once activated, p53 either induces cell-cycle arrest at G1 or G2 by increasing the transcription of p21 gene or initiate apoptosis [20]. Several of transcriptional targets of p53 including p21 and 14-3-3 $\gamma$ can inhibit cdc2. 14-3-3 $\gamma$ anchors cdc2 in the cytoplasm and inhibits the activation of cyclin B-cdc2, thereby deficiency of activated cyclin B-cdc2 induces cell cycle arrest at G2/M checkpoint. This study demonstrated that ETA treatment upregulated p21 and 14-3-3 $\gamma$ and downregulated cdc2 and cyclin B, which suggests that PEA induces cell cycle arrest and subsequent progress to apoptosis.

Taken together, PEA has a strong apoptotic effect on chemoresistant YD-9 OSC via activation of caspases, mitochondrial events and regulation of cell cycle genes. It remains also an open question through which exact molecular mechanism PEA induces apoptosis in chemoresistant OSC cells.

\section{Acknowledgments}

This study was supported by grant of Kosin University College of Medicine (2009) and this study was supported by for two years Pusan National University research grant.

\section{References}

1. Allam, M., R. Bertrand, G. Zhang-Sun, J. Pappas, and J. Viallet. 1997. Cholera toxin triggers apoptosis in human lung cancer cell lines. Cancer Res. 57, 2615-2618.

2. Andersson, Y., S. Juell, and O. Fodstad. 2004. Downregulation of the antiapoptotic MCL-1 protein and apoptosis in MA-11 breast cancer cells induced by an anti-epidermal growth factor receptor-Pseudomonas exotoxin a immunotoxin. Int. J. Cancer 112, 475-483.

3. Bhattacharjee, R. N., K. S. Park, S. Uematsu, K. Okada, K. Hoshino, K. Takeda, O. Takeuchi, S. Akira, T. Iida, and T. Honda. 2005. Escherichia coli verotoxin 1 mediates apoptosis in human HCT116 colon cancer cells by inducing overexpression of the GADD family of genes and $S$ phase arrest. FEBS Lett 579, 6604-6610.

4. Brinkmann, U. and I. Pastan. 1994. Immunotoxins against cancer. Biochim Biophys. Acta 1198, 27-45.

5. Cho. S. J., N. S. Kang, S. Y. Park, B. O. Kim, D. K. Rhee, 
and S. Pyo. 2003. Induction of apoptosis and expression of apoptosis related genes in human epithelial carcinoma cells by Helicobacter pylori VacA toxin. Toxicon. 42, 601-611.

6. Coley, W. B. 1991. The treatment of malignant tumors by repeated inoculations oferysipelas. With a report of ten original cases. 1893. Clin. Orthop. Relat. Res. 262, 3-11.

7. Crowe, D. L. and U. K. Sinha. 2006. p53 apoptotic response to DNA damage dependent on bcl2 but not bax in head and neck squamous cell carcinoma lines. Head Neck 28, 15-23.

8. Dang, L. H., C. Bettegowda, D. L. Huso, K. W. Kinzler, and B. Vogelstein. 2001. Combination bacteriolytic therapy for the treatment of experimental tumors. Proc. Natl. Acad Sci. USA 98, 15155-15160.

9. Decker, T., M. Oelsner, R. J. Kreitman, G. Salvatore, Q. C. Wang, I. Pastan, C. Peschel, and T. Licht. 2004. Induction of caspase-dependent programmed cell death in B-cell chronic lymphocytic leukemia by anti-CD22 immunotoxins. Blood 103, 2718-2726.

10. Du, C., M. Fang, Y. Li, L. Li, and X. Wang. 2000. Smac, a mitochondrial protein that promotes cytochrome c-dependent caspase activation by eliminating IAP inhibition. Cell 102, 33-42.

11. Grassme, H., V. Jendrossek, and E. Gulbins. 2001. Molecular mechanisms of bacteria induced apoptosis. Apoptosis 6, 441-445.

12. Hamood, A. N., J. A. Griswold, and C. M. Duhan. 1996. Production of extracellular virulence factors by Pseudomonas aeruginosa isolates obtained from tracheal, urinary tract, and wound infections. J. Surg. Res 61, 425-432.

13. Hande, K. R. 1998. Etoposide: four decades of development of a topoisomerase II inhibitor. Eur. J. Cancer 34, 1514-1521.

14. Heath-Engel, H. M. and C. A. Lingwood. 2003. Verotoxin sensitivity of ECV304 cells in vitro and in vivo in a xenograft tumour model: VT1 as a tumour neovascular marker. Angiogenesis 6, 129-141.

15. Hunter, C. A., D. Yu, M. Gee, C. V. Ngo, C. Sevignani, M. Goldschmidt, T. V. Golovkina, S. Evans, W.F. Lee, and A. Thomas-Tikhonenko. 2001. Cutting edge: systemic inhibition of angiogenesis underlies resistance to tumors during acute toxoplasmosis. J. Immunol. 166, 5878-5881.

16. Iglewki, B. H., P. V. Liu, and D. Kabat. 1977. Mechanism of action of Pseudomonas aeruginosa exotoxin Aiadenosine diphosphate-ribosylation of mammalian elongation factor 2 in vitro and in vivo. Infect. Immun 15, 138-144.

17. Jain, R. K. and N. S. Forbes, 2001. Can engineered bacteria help control cancer? Proc. Natl. Acad Sci. USA 98, 14748-14750.

18. Jenkins, C. E., A. Swiatoniowski, A. C. Issekutz, and T. J. Lin. 2004. Pseudomonas aeruginosa exotoxin A induces human mast cell apoptosis by a caspase- 8 and -3-dependent mechanism. J. Biol. Chem 279, 37201-37207.

19. Kiyokawa, N., T. Mori, T. Taguchi, M. Saito, K. Mimori, T. Suzuki, T. Sekino, N. Sato, H. Nakajima, Y. U. Katagiri, T. Takeda, and J. Fujimoto. 2001. Activation of the caspase cascade during Stx1-induced apoptosis in Burkitt's lymphoma cells. J. Cell Biochem 81, 128-142.

20. Ko, L. J. and C. Prives. 1996. p53: puzzle and paradigm. Genes Dev. 10, 1054-1072.

21. Koo, H. M., M. VanBrocklin, M. J. McWilliams, S. H. Leppla, N. S. Duesbery, and G. F. Woude. 2002. Apoptosis and melanogenesis in human melanoma cells induced by anthrax lethal factor inactivation of mitogen-activated protein kinase kinase. Proc. Natl. Acad Sci. USA 99, 3052-3057.

22. Lee, E. J., J. Kim, S. A. Lee, E. J. Kim, Y. C. Chun, M. H. Ryu, and J. I. Yook. 2005. Characterization of newly established oral cancer cell lines derived from six squamous cell carcinoma and two mucoepidermoid carcinoma cells. Exp. Mol. Med. 37, 379-390

23. Lee, S. Y., R. P. Cherla, I. Caliskan, and V. L. Tesh. 2005. Shiga, toxin 1 induces apoptosis in the human myelogenous leukemia cell line THP-1 by a caspase-8-dependent, tumor necrosis factor receptor-independent mechanism. Infect. Immun. 73, 5115-5126.

24. Morimoto, H., B. J. Bonavida. 1992. Diphtheria toxin- and Pseudomonas A toxin-mediated apoptosis. ADP ribosylation of elongation factor-2 is required for DNA fragmentation and cell lysis and synergy with tumor necrosis factor-alpha. Immunol. 149, 2089-2094.

25. Nauts, H. C. and J. R. McLaren. 1990. Coley toxins--the first century. Adv. Exp. Med Biol. 267, 483-500.

26. Pastan, I. 2003. Immunotoxins containing Pseudomonas exotoxin A: a short history. Cancer Immunol. Immunother. 52, 338-341.

27. Pastan, I. and D. FitzGerald. 1991. Recombinant toxins for cancer treatment. Science 254, 1173-1177.

28. Roh, M. S., C. W. Kim, B. S. Park, G. C. Kim, J. H. Jeong, H. C. Kwon, D. J. Suh, K. H. Cho, S. B. Yee, and Y. H. Yoo. 2004. Mechanism of histone deacetylase inhibitor Trichostatin A induced apoptosis in human osteosarcoma cells. Apoptosis 9, 583-589.

29. Sarkar, F. H. and Y. Li. 2002. Mechanisms of cancer chemoprevention by soy isoflavone genistein. Cancer Metastasis Rev. 21, 265-280.

30. Schumann, J., S. Angermuller, R. Bang, M. Lohoff, and G. J. Tiegs. 1998. Acute hepatotoxicity of Pseudomonas aeruginosa exotoxin $\mathrm{A}$ in mice depends on $\mathrm{T}$ cells and TNF. Immunol. 161, 5745-5754.

31. Thorburn, J., A. E. Frankel, and A. Thorburn. 2003. Apoptosis by leukemia cell-targeted diphtheria toxin occurs via receptor-independent activation of Fas-associated death domain protein. Clin. Cancer Res. 9, 861-865.

32. Tong, D., M. Poot, D. Hu, and D. Oda. 2000. 5-Fluorouracilinduced apoptosis in cultured oral cancer cells. Oral. Oncol. 36, 236-241.

33. Van Delden, C., B. H. Iglewski. 1998. Cell-to-cell signaling and Pseudomonas aeruginosa infections. Emerg. Infect. Dis. 4, 551-560.

34. Yuan, J. 1996. Evolutionary conservation of a genetic pathway of programmed cell death. J. Cell Biochem 60, 4-11. 
초록 : 항암제에 저항성을 가지는 YD-9 human oral squamous carcinoma cell line에서 Pseudomonas aeruginosa exotoxin A의 p53 단백질 누적과 caspase를 활성화 경로를 통 해 유도된 세포자멸사

김규천 ${ }^{1}$ 길영기*

(고신대학교 의과대학 해부학교실, ${ }^{1}$ 부산대학교 치의학전문대학원 구강해부학교실)

구강편평상피암종은 말기에서 종종 화학치료요법제들이 유도하는 세포자멸사에 저항성을 보인다. 박테리아의 독에 대한 진전된 이해는 암치료에 대한 새로운 치료전략으로 제기되어지고 있다. 본 연구는 Pseudomonas aeruginosa exotoxin A (PEA)가 세포자멸사 기작을 통해 항암제에 저항성을 보이는 YD-9 구강편평상피암종의 생존율을 현격 하게 떨어뜨림을 설명하고 있다. 세포자멸사현상은 핵의 형태학적 변화와 DNA 분절 생성을 통해 입증되었다. PEA는 caspase-3, -6, -9의 분절과 활성화를 일으켰다. 그리고 이러한 반응들은 caspase의 기질에 해당하는 poly (ADP-ribose) polymerase (PARP), DFF45, 그리고 lamin A의 단백질 분해를 야기했다. 사립체 막전위 감소, cytochrome c와 Smac/DIABLO의 사립체로부터 세포질로의 유리, 그리고 $\mathrm{AIF}$ 의 사립체에서 핵으로 이동 등이 관찰되 었다. p53, p21 그리고 14-3-3y는 증가되는 반면 cyclin B와 cdc2는 감소되었다. 이상의 결과들을 종합해 보면 PEA는 caspase를 활성화시키고, 사립체에 변화를 야기시키고 더 나아가서 세포주기 유전자를 조절함으로써 항암제에 대한 강한 저항성을 보이는 YD-9 세포에서 세포자멸사를 유도한다. 